World wide web

\section{Information exchange is two way}

\section{H Zia, J A Razzak, H Zafar}

\section{The impact of the world wide web on emergency medicine in developing countries}

A key element in the evolution of emergency medicine (EM) as a global medical specialty is the exchange of information. This includes links between international organisations, academic institutions, and individuals in countries where EM is at various levels of development. Medical journals and other printed publications related to EM have also been a major source of information exchange between countries. ${ }^{1}$ The future of our specialty therefore depends on the quality of information exchanged, how it is disseminated, and to whom the information is given.

Limiting this exchange is the expense and time delay in delivering paper journals. In contrast, the electronic media does not have these restrictions. The potential applications of the internet to international education are limited only by the quality of its content and the imagination of its users.

The world wide web is becoming an increasingly important source of information and is now the medium of choice for international communication. ${ }^{2}$ Today, most countries have access to the internet, suggesting that in the future remaining intellectually isolated from the standards of emergency care will be increasingly difficult.

Until recently the electronic transfer of information has had only a minor role in the international development of EM. ${ }^{3}$ This is surprising in view of the advantages and the minimal technology required. Development mostly depends on system changes and not on the importation of expensive medical equipment. ${ }^{45}$ An example of this is the application of evidence based medicine techniques and best evidence topics reports. These have the potential to help physicians evaluate information supporting change before new systems are implemented or valuable resources are invested. Ironically, the establishment of new systems in developing countries may actually improve the evidence, as it will provide new opportunities to reexamine the merits of how EM is practised in mature systems.

Developing countries have a wealth of experience in dealing with conditions that present with varying frequency elsewhere. These include sickle cell crisis, ectopic pregnancies, and infectious diseases. Unfortunately, many conditions are very common all over the world. The incidence of self poisoning and trauma is increasing in developing countries (HA Chotani, et al, 4th world conference on injury prevention and control, Amsterdam, the Netherlands, 1998). ${ }^{6-9}$ There is also the significant burden of dealing with time sensitive illness such as cardiovascular diseases and obstetrics complication in places where the prehospital system is limited. ${ }^{10-13}$

It is important that this knowledge and experience is fed into the EM world reservoir of knowledge so all can benefit. To achieve this, centres throughout the world need to be involved in clinical debate on the management of EM conditions as well as identifying topics relevant to their practice. Above all, international patient outcome data must become available and comparable; only that will guide the search for international standards of emergency care.

To facilitate such developments, the World Health Organisation has successfully convinced medical publishers to provide physicians and scientist in developing countries with cheap access to research journal via the internet. As a result recent issues of the New England Journal of Medicine and the BMJ publishing group are extending free access to over 100 of the low income countries. ${ }^{14} 15$ However, these developments are only one part of what is needed to improve the use of emergency care information exchange in the developing world. ${ }^{34}$ Journals also need to provide space to publish evidence based medicine techniques, best evidence topics reports, and clinical review topics relevant to developing countries.
If the EMJ really wants to make an enduring global contribution they need to focus on the content of their publication and provide some space to cover the emergency care and concerns of underdeveloped regions. Equally those practising in these areas need to be proactive and learn how to report best evidence topics and be involved in the increasing debate about improving emergency care worldwide.

Emerg Med J 2002;19:380

\section{Authors' affiliations}

H Zia, Accident and Emergency Medicine, Newcastle General Hospital, UK

J A Razzak, Section of Emergency Medicine, Department of Surgery, Yale University School of Medicine, New Haven, USA

H Zafar, Department of Surgery, The Aga Khan University Hospital, Karachi, Pakistan

Correspondence to: $\mathrm{Dr} \mathrm{H}$ Zia

ziauddin_hassan@yahoo.com

\section{REFERENCES}

1 Arnold JL. International emergency medicine and the recent development of emergency medicine worldwide. Ann Emerg Med 1999:33:97-103.

2 Keyes LE, Holliman CJ. Reference listing of international emergency medicine journals and web sites. Ann Emerg Med 1999:34:786-9.

3 Holliman CJ, Kirsch TD, Green G. Guideline for evaluation of international emergency medicine assistance and development projects. Ann Emerg Med 1997;30:81 1-15. 4 Aghababian RV, Levy K, Moyer P, et al. Integration of United states emergency medicine concepts into emergency services in the New Independent States. Ann Emerg Med 1995:26:368-75.

5 Doezma D, Sklar DP, Roth PB. Development of emergency medical services in Costa Rica. JAMA 1999;265: 188-90.

6 Kumar A, Kavitha C, Vibhu N, et al. Early development of emergency medicine in Chennai (Madras), India. Ann Emerg Med 1998:32:604-7.

7 Mehdi IJ. Emergency medicine in Pakistan. Ann Emerg Med 1996;27:84-8.

8 Raftery KA. Emergency medicine in southern Pakistan. Ann Emerg Med 1996;27:79-83.

9 Razzak JA, David CC, Rifat R. Emergency medical services and cultural determinants of an emergency in Karachi, Pakistan. Prehospital Emergency Care 2001;15:312-16.

10 Razzak JA, Luby SP. Estimating deaths and injuries due to road traffic accident in Karachi, Pakistan, through the capture-recapture method. Int $J$ Epidemiol capture-recapture me

11 Fikree FF, Karim MS, Midhet F, et al. Causes of reproductive age mortality in low socio-economic settlements of Karachi. Journal of the Pakistan Medical Assocociation 1993:431:208-14

12 Kirsch TD, Hilwig WK, Holder Y. Epidemiology and practice of emergency medicine in a developing country. Ann Emerg Med 1995;26:361-7.

13 Sklar DP. Emergency medicine in the developing world. Am J Emerg Med 1988:6:390-3.

14 Smith R, Williamson R. BM journal free to the developing world. BM ; 324:380

15 Shaywitz DA, Ausiello DA. The $15 \%$ solution of majority heath concerns. Nature 2002:415:575. 